\title{
TP53 codon 72 polymorphism as a risk factor for cardiovascular disease in a Brazilian population
}

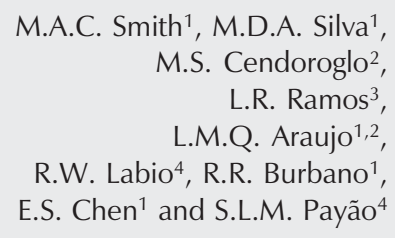

\author{
1Disciplina de Genética, Departamento de Morfologia e Genética, \\ ${ }^{2}$ Disciplina de Geriatria, ${ }^{3}$ Departamento de Medicina Preventiva, \\ Escola Paulista de Medicina, Universidade Federal de São Paulo, São Paulo, \\ SP, Brasil \\ ${ }^{4}$ Disciplina de Genética e de Biologia Molecular, Hemocentro, \\ Faculdade de Medicina de Marília, Marília, SP, Brasil
}

\section{Correspondence M.A.C. Smith \\ Disciplina de Genética \\ Departamento de Morfologia e \\ Genética \\ EPM, UNIFESP \\ Rua Botucatu, 740 \\ Edifício Leitão da Cunha \\ 04023-900 São Paulo, SP \\ Brasil \\ Fax: +55-11-5576-4264 \\ E-mail: macsmith.morf@epm.br \\ Research supported by FAPESP, CNPq and CAPES.}

Received February 2, 2007 Accepted Julho 31, 2007

\begin{abstract}
TP53, a tumor suppressor gene, has a critical role in cell cycle, apoptosis and cell senescence and participates in many crucial physiological and pathological processes. Identification of TP53 polymorphism in older people and age-related diseases may provide an understanding of its physiology and pathophysiological role as well as risk factors for complex diseases. TP53 codon 72 (TP53:72) polymorphism was investigated in 383 individuals aged 66 to 97 years in a cohort from a Brazilian Elderly Longitudinal Study. We investigated allele frequency, genotype distribution and allele association with morbidities such as cardiovascular disease, type II diabetes, obesity, neoplasia, low cognitive level (dementia), and depression. We also determined the association of this polymorphism with serum lipid fractions and urea, creatinine, albumin, fasting glucose, and glycated hemoglobin levels. DNA was isolated from blood cells, amplified by PCR using sense 5'-TTGCCGTCCCAAGCAATGGATGA-3' and antisense 5'-TCTGGGAAGGGACAGAAGATGAC-3' primers and digested with the BstUI enzyme. This polymorphism is within exon 4 at nucleotide residue 347. Descriptive statistics, logistic regression analysis and Student $t$-test using the multiple comparison test were used. Allele frequencies, R $(\operatorname{Arg})=0.69$ and $\mathrm{P}(\mathrm{Pro})=0.31$, were similar to other populations. Genotype distributions were within Hardy-Weinberg equilibrium. This polymorphism did not show significant association with any age-related disease or serum variables. However, R allele carriers showed lower HDL levels and a higher frequency of cardiovascular disease than $\mathrm{P}$ allele subjects. These findings may help to elucidate the physiopathological role of TP53:72 polymorphism in Brazilian elderly people.
\end{abstract}

Key words

- Cardiovascular risk factors

- HDL

- Lipid metabolism

- TP53 polymorphism codon 72

- Age-related diseases

- Elderly cohort .......................

\section{Introduction}

TP53, a tumor suppressor gene, has a critical role in cell cycle, apoptosis and cell senescence and participates in many crucial physiological and pathological processes (1). Also, TP53 is central in protecting against neoplastic diseases in humans and may affect survival (2).

TP53 plays an important role in regulat- 
ing vascular smooth muscle cell growth and may mediate an abnormal occurrence of apoptosis in atherosclerotic lesions by attenuating or accelerating the apoptotic death process (3). This protein has been observed in unstable atherosclerotic carotid plaque and the p53 pathway may be activated by lipid peroxidation products, as observed in human neuroblastoma cells (4). Furthermore, the involvement of p53 in some age-associated morbidities such as diabetes (5) and fatty liver diseases (6) has also been described.

Functional analysis of TP53 codon 72 (TP53:72) variants showed differences in their transactivating activity, transforming capacity and apoptosis induction as well as in binding a variety of proteins. TP53 variant protein R72 (Arg) is significantly more efficient than P72 (Pro) in inducing apoptosis while P72 appears to induce a higher level of G1 arrest $(1,7)$.

A remarkable activity of p53 has been described in mutant mice which display early aging-associated phenotypes $(8,9)$. Among continental Italian and Sardinian centenarians, these variants did not have a sufficient impact on age-related mortality so as to alter gene frequency with age (2). On the other hand, a prospective study of 1226 people aged 85 years and over showed a $41 \%$ survival rate for Pro/Pro genotype carriers (10).

An association between RR genotype and minimum lumen diameter 3 months after angioplasty has been reported in Japanese patients (11). Zee et al. (12) demonstrated that TP53 haplotypes, including R72P polymorphism, have protective effects on restenosis after angioplasty mainly due to the P72 allele. Bonafe et al. (13) observed a higher extension of oxidative stress-induced apoptosis in isolated fibroblast and lymphocyte cells from Italian centenarians and sexagenarians with the RR genotype. The RR genotype modulates in vivo ischemia-induced cell death in patients with acute coronary syndrome (13) and was also found to be associ- ated with a poor outcome in patients with traumatic brain injury (14).

Investigation of this polymorphism in 109 Alzheimer disease patients did not show association and did not reveal an interactive effect with apolipoprotein E allele $\varepsilon 4$ (15).

In the present study, we determined allele and genotype frequencies and the association of TP53:72 polymorphism with morbidities such as cardiovascular disease, type II diabetes, obesity, neoplasia, low cognitive level (dementia), and depression, as well as with serum lipid and protein levels, in a cohort of elderly subjects followed in longitudinal study in São Paulo, Brazil. To our knowledge, there are no literature reports investigating the association of TP53:72 with all of these morbidities. Lipids, proteins, urea, creatinine, fasting glucose, and glycated hemoglobin were also investigated concerning this polymorphism.

\section{Material and Methods}

\section{Population}

The study population consisted of 383 participants from an Elderly Longitudinal Study (16). This study began in 1991 and originally involved 1667 people over the age of 66 years living in a São Paulo community, Brazil. Subjects were clinically evaluated every two years and a subsample of 383 in wave 4 (2000-2001) were invited to participate in the present study. This population was composed of individuals of European $(89.2 \%)$, Japanese (3.3\%), Middle Eastern $(1.81 \%)$, and mixed and/or other origin $(5.70 \%)$. The mean age of this population cohort was $79.80 \pm 5.32$ years (range: $66-97$ years).

Clinical inquiries were performed to obtain information about medical history, current medication use, lifestyle, and anthropometric measurements. Physicians performed a physical exam and blood samples were collected for laboratory procedures. The 
Research Ethics Committee of UNIFESP approved this study and all participants gave written informed consent.

Subjects were considered positive for cardiovascular disease when they self-reported previous myocardial infarction and/ or coronary heart disease, cerebrovascular disease and/or transitory ischemic attacks and were also taking specific medication prescribed by physicians. Those currently taking insulin or oral medication and those with fasting glucose equal to or above 126 $\mathrm{mg} / \mathrm{dL}$ were considered positive for type II diabetes (17). Subjects were considered to be positive for neoplasia when they selfreported a previous diagnosis with confirmation by the results of histological exams in their medical records. Subjects with a body mass index above $27 \mathrm{~kg} / \mathrm{m}^{2}$ were considered to be obese $(18,19)$. Cognitive function was evaluated by the Mini-Mental State Examination screening instrument (20) validated for the Brazilian population (21). A Mini-Mental State Examination score of less than 24 (of 30) has $80-90 \%$ sensitivity and $80 \%$ specificity for discriminating subjects with low cognition level, roughly classified as dementia, from normal subjects $(21,22)$. Depression was characterized by a score above 5 in a validated Brazilian version of the instrument from Older Americans Resources and Services (23).

Although some studies have shown that self-reported past history and medical records are usually concordant for selected medical conditions in the elderly (24), past histories were only accepted when there was also evidence in physical examinations, ECG, CT-scan or physician reports.

TP53:72 polymorphism was also investigated in 56 elderly healthy controls, ranging in age from 56 to 95 years (mean age: $73.07 \pm 8.18$ years) and 59 young healthy controls ranging in age from 7 to 23 years (mean age: $20.3 \pm 1.5$ years). The elderly control sample was composed of $89.3 \%$ European, 5.4\% Japanese, 1.8\% Afro-Brazil- ian, and 3.5\% mixed origin subjects. The young control sample was composed of 89.8\% European, $8.5 \%$ Japanese, and $1.6 \%$ mixed origin subjects.

\section{Laboratory exams}

Lipid and lipid fraction measurements were performed by routine enzymatic tests. Creatinine, albumin, urea, and fasting serum glucose levels were investigated by usual colorimetric, kinetic and UV tests. Glycated hemoglobin levels were analyzed by highperformance liquid chromatography (25).

\section{DNA extraction}

Blood was collected into tubes containing $0.1 \%$ EDTA and genomic DNA was isolated using procedures modified from Lahiri and Nurnberger (26).

\section{Genotyping}

TP53 R72P polymorphism was analyzed using procedures modified from Helland et al. (27) and Ara et al. (28). A 199-bp sequence containing the polymorphic site was amplified by PCR using sense 5'-TTGCC GTCCCAAGCAATGGATGA-3' and antisense 5'-TCTGGGAAGGGACAGAAGAT GAC-3' primers.

Each PCR mixture contained $50 \mathrm{ng}$ genomic DNA and PCR buffer, $\mathrm{MgCl}_{2}$, dNTPs, Taq polymerase, and primers. The mixture was heated for $4 \mathrm{~min}$ at $95^{\circ} \mathrm{C}$ and underwent 35 cycles of amplification: annealing $\left(55^{\circ} \mathrm{C}\right.$ for $30 \mathrm{~s})$, extension $\left(72^{\circ} \mathrm{C}\right.$ for $\left.45 \mathrm{~s}\right)$ and denaturation $\left(94^{\circ} \mathrm{C}\right.$ for $\left.45 \mathrm{~s}\right)$. The PCR product was digested with $B s t \mathrm{UI}$ for $4 \mathrm{~h}$ at $60^{\circ} \mathrm{C}$, producing two fragments of 113 and $86 \mathrm{bp}$ in relation to the $\mathrm{R}$ allele and a fragment with 199 bp in relation to the $\mathrm{P}$ allele.

Restriction fragment length polymorphism products were analyzed on 4\% GTG agarose gel and stained with ethidium bromide. Figure 1 shows the TP53 R72P alleles 
and genotypes obtained from restriction fragment analysis.

\section{Statistical analysis}

Descriptive statistics, logistic regression analysis, chi-square test, and $t$-test were performed using SPSS 10.0. Genotype and allele frequencies were calculated by allele counting as described by Emery (29). Genotype distribution was investigated in terms of Hardy-Weinberg equilibrium. Two allele groups were considered for statistical analysis: one with a $\mathrm{P}$ allele $(\mathrm{PP}+\mathrm{PR}$ genotypes together) and the other with a non-P allele (RR genotype). The mean age of subjects with the $\mathrm{P}$ allele was $79.57 \pm 5.40$ years and the mean age of subjects with the non-P allele was $80.06 \pm 5.23$ years. Age comparison between allele groups did not show a significant difference $(\mathrm{t}=0.894$; d.f. $=381$; $\mathrm{P}=\mathrm{ns})$. Gender association with morbidity was also evaluated in the entire sample using the chi-square test $(\alpha=0.05)$.

Logistic regression analysis for the investigation of polymorphism association with morbidity was performed considering the allele as a dependent variable and morbidity, age and sex as co-variables in the model. Odds ratios and $95 \%$ confidence interval were calculated using the SPSS 10.0 software. The Student $t$-test was used to compare laboratory findings for $\mathrm{P}$ and non- $\mathrm{P}$ allele carriers $(\alpha=0.05)$.

\section{Results}

The allele frequencies observed in our population were 0.31 for the $\mathrm{P}$ allele and 0.69 for the $\mathrm{R}$ allele. Observed genotype frequencies were 0.47 for RR, 0.44 for PR, and 0.09 for PP. Genotype distributions were within Hardy-Weinberg equilibrium for the whole sample, elderly and young controls and for the groups with cardiovascular disease, type II diabetes, obesity, and neoplasia (data not shown). Genotype distribution and allele frequency for the whole sample and the subsamples are shown in Table 1.

Logistic regression analysis revealed a tendency of the $\mathrm{R}$ allele (non-P allele) to associate with cardiovascular disease (Table 2). Table 3 shows descriptive statistics and Student $t$-test values for the two allele groups concerning laboratory findings. We detected an association of the $\mathrm{R}$ allele with lower

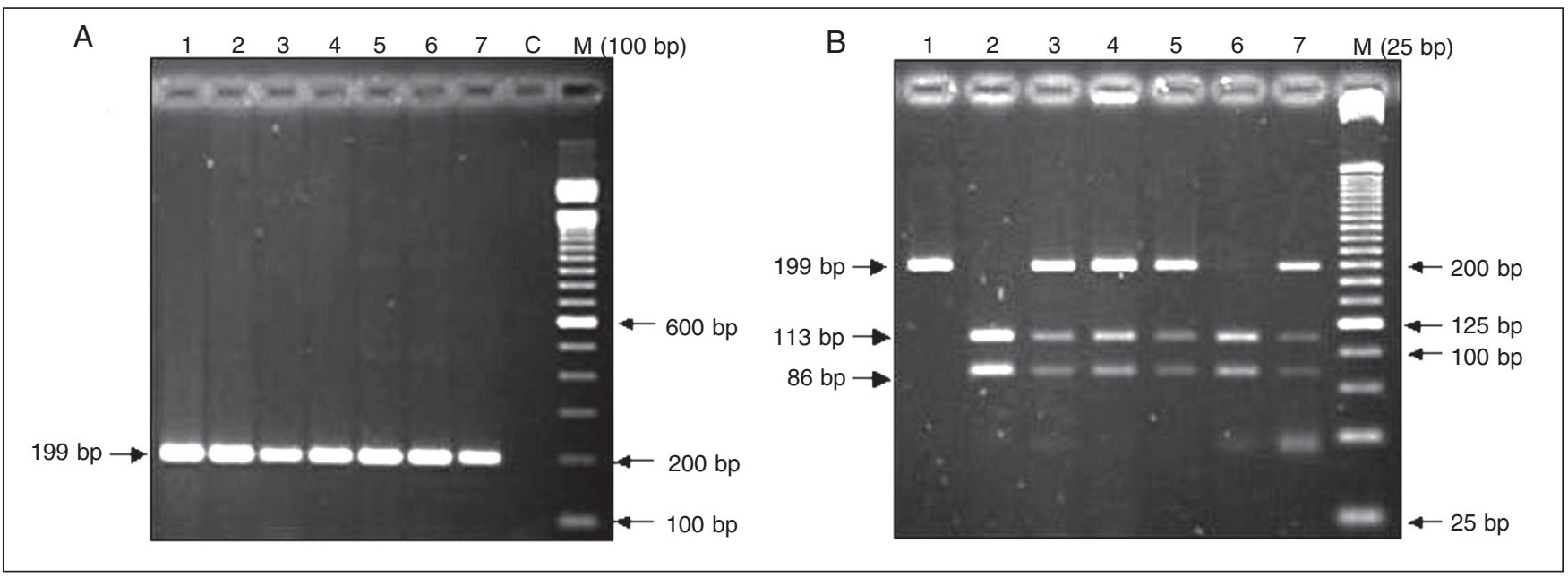

Figure 1. A, PCR product amplification of TP53 codon 72 gene. Lanes 1-7: PCR products; $C$ : negative control and M (100 bp): $100-b p$ DNA marker (Gibco, Gaithersberg, MD, USA). B, Restriction fragment length polymorphism on 4\% GTG agarose gel. Lane 1: P (Pro) allele (199 bp); lanes 2 and 6 : R (Arg) allele (113 + 86 bp), and lanes 3, 4, 5, and 7: PR genotype (199 + $113+86$ bp). M (25 bp): 25-bp DNA marker (Gibco). 
Table 1. Number and distribution of TP53:72 genotypes and alleles in a Brazilian elderly cohort and in elderly and young healthy controls.

\begin{tabular}{|c|c|c|c|c|c|c|c|}
\hline & \multicolumn{5}{|c|}{ Genotypes } & \multicolumn{2}{|c|}{ Allele frequencies } \\
\hline & PP & PR & $\mathrm{RR}$ & & Total & $\mathrm{P}$ & $\mathrm{R}$ \\
\hline Whole sample & 33 & 169 & 181 & & 383 & 0.3068 & 0.6932 \\
\hline Male & 15 & 55 & 51 & & 121 & 0.3512 & 0.6488 \\
\hline Female & 18 & 114 & 130 & & 262 & 0.2863 & 0.7137 \\
\hline Elderly controls & 3 & 21 & 32 & & 56 & 0.2411 & 0.7589 \\
\hline \multirow[t]{2}{*}{ Young controls } & 3 & 31 & 35 & & 59 & 0.2681 & 0.7319 \\
\hline & \multicolumn{3}{|c|}{ Affected subjects } & \multicolumn{2}{|c|}{ Total } & $\mathrm{P}$ & $\mathrm{R}$ \\
\hline Cardiovascular & 5 & 32 & 46 & 83 & 382 & 0.2530 & 0.7470 \\
\hline Type II diabetes & 26 & 102 & 114 & 242 & 382 & 0.3182 & 0.6818 \\
\hline Obesity & 12 & 55 & 60 & 127 & 308 & 0.3110 & 0.6890 \\
\hline Depression & 4 & 40 & 27 & 71 & 354 & 0.3380 & 0.6620 \\
\hline Low cognitive level & 0 & 17 & 13 & 30 & 376 & 0.2833 & 0.7167 \\
\hline Neoplasia & 2 & 20 & 19 & 41 & 378 & 0.2927 & 0.7073 \\
\hline
\end{tabular}

Table 2. Logistic regression results concerning association between morbidities and TP53:72 polymorphism in a cohort from a Brazilian elderly population.

\begin{tabular}{|c|c|c|c|c|}
\hline \multirow[t]{2}{*}{ Variables } & \multirow[t]{2}{*}{$P$ value } & \multirow{2}{*}{$\frac{\text { Odds ratio }}{\mathrm{P} \text { allele/non-P allele }}$} & \multicolumn{2}{|c|}{$95 \%$ confidence interval } \\
\hline & & & Lower & Upper \\
\hline Cardiovascular disease & 0.071 & 0.638 & 0.389 & 1.045 \\
\hline Type II diabetes & 0.865 & 1.000 & 0.629 & 1.476 \\
\hline Obesity & 0.662 & 0.901 & 0.565 & 1.438 \\
\hline Depression & 0.075 & 1.634 & 0.953 & 2.801 \\
\hline Low cognitive level & 0.599 & 1.226 & 0.574 & 2.615 \\
\hline Neoplasia & 0.952 & 1.020 & 0.531 & 1.962 \\
\hline
\end{tabular}

Table 3. Descriptive statistics concerning $P$ allele and non-P allele carriers and laboratory findings.

\begin{tabular}{|c|c|c|c|c|}
\hline & \multicolumn{2}{|c|}{$\mathrm{P}$ allele carriers } & \multicolumn{2}{|c|}{ Non-P allele carriers } \\
\hline & $\mathrm{N}$ & Mean \pm SD & $\mathrm{N}$ & Mean \pm SD \\
\hline Triglycerides & 135 & $147.53 \pm 77.75$ & 112 & $151.89 \pm 62.96$ \\
\hline Cholesterol & 135 & $216.74 \pm 41.45$ & 112 & $214.88 \pm 44.20$ \\
\hline HDL & 135 & $55.96 \pm 15.27$ & 111 & $52.41 \pm 12.57$ \\
\hline LDL & 130 & $131.06 \pm 33.88$ & 109 & $132.78 \pm 38.39$ \\
\hline VLDL & 131 & $27.62 \pm 11.45$ & 110 & $29.73 \pm 11.00$ \\
\hline Creatinine & 130 & $0.9669 \pm 0.2501$ & 108 & $0.9324 \pm 0.2254$ \\
\hline Urea & 131 & $40.95 \pm 13.31$ & 108 & $39.81 \pm 11.72$ \\
\hline Albumin & 130 & $4.0669 \pm 0.3099$ & 108 & $4.0019 \pm 0.3399$ \\
\hline Fasting glucose & 180 & $98.07 \pm 35.32$ & 168 & $100.10 \pm 28.61$ \\
\hline Glycated hemoglobin & 105 & $4.8857 \pm 1.3273$ & 114 & $5.0342 \pm 1.3917$ \\
\hline
\end{tabular}


HDL levels $(P=0.047)$. Serum triglyceride, total cholesterol, VLDL, LDL, urea, creatinine, albumin, fasting glucose, and glycated hemoglobin levels did not show significant differences between $\mathrm{P}$ allele carriers and non-P allele carriers (Student $t$-test).

\section{Discussion}

Studies conducted on older populations have the advantage of demonstrating specific aspects of the aging process. Our sample was mostly composed of European descendents and our results concerning allele and genotype frequencies are similar to those reported in other studies on populations of the same ethnic composition. Another study on a Brazilian adult population reported the following genotype frequencies: $R R=0.518$, $\mathrm{PR}=0.405$, and $\mathrm{PP}=0.078$ (30). A study on a Chilean adult population sample reported similar frequencies: $\mathrm{RR}=0.472, \mathrm{PR}=0.453$, and $\mathrm{PP}=0.075$ (31), as also reported for a Mexican sample $(\mathrm{RR}=0.45, \mathrm{PR}=0.62$, and $\mathrm{PP}=0.08)(32)$.

Female gender was associated with obesity in our sample $(\mathrm{P}=0.011)$, confirming the findings of a Brazilian epidemiological study involving residents over 60 years in the Bambuí community, Minas Gerais State (33). Another epidemiological investigation in the Northeast and Southeast regions of Brazil also showed higher a prevalence of obesity among women older than 50 years (34).

Genotype distribution was within HardyWeinberg equilibrium in the whole sample and in all the subsamples, except for the depression and low cognitive level groups. TP53 variants did not have a sufficient impact on age-related mortality so as to alter gene frequency in comparison with the young control group $(\mathrm{P}=0.081)$ in this sample.

TP53:72 polymorphism did not show a significant association with any age-related morbidity or serum variable. Our population is mainly composed of European descendants, especially from Portugal, Spain, and Italy. In Spanish and Italian populations, the $\mathrm{R}$ allele has been associated with restenosis after angioplasty and with a greater extent of cells with oxidative stress in centenarians and sexagenarians $(2,12)$. This ethnic composition may account for the observed tendency of the $\mathrm{R}$ allele to associate with cardiovascular disease and lower HDL levels.

The relationship between TP53 and lipid metabolism is not well known but many reports support correlations. Lower levels of HDL lipoprotein have been considered to be an independent risk factor for cardiovascular disease and type II diabetes (35). Moreover, modification of low-density lipoprotein by endothelial cells has been associated with lipid peroxidation and with degradation of low-density lipoprotein phospholipids (36). In addition, the lipid peroxidation product has also been considered a potential trigger of the p53 pathway in human neuroblastoma cells. Patients with acute myocardial infarction showed four times higher levels of serum oxidized LDL compared to control (37).

Our findings also did not show an association of the polymorphism with type II diabetes or with some serum variables associated with impaired renal function, although the p53 pathway contributes to an altered neovascularization process in diabetes (38).

These findings may help to elucidate the physiopathological role of TP53:72 polymorphism in elderly Brazilian people. 


\section{References}

1. Dumont P, Leu JI, Della Pietra AC III, George DL, Murphy M. The codon 72 polymorphic variants of p53 have markedly different apoptotic potential. Nat Genet 2003; 33: 357-365.

2. Bonafe M, Olivieri F, Mari D, Baggio G, Mattace R, Berardelli M, et al. P53 codon 72 polymorphism and longevity: additional data on centenarians from continental Italy and Sardinia. Am J Hum Genet 1999; 65: 1782-1785.

3. Geng YJ. Biologic effect and molecular regulation of vascular apoptosis in atherosclerosis. Curr Atheroscler Rep 2001; 3: 234-242.

4. Shibata T, lio K, Kawai $Y$, Shibata N, Kawaguchi M, Toi S, et al. Identification of a lipid peroxidation product as a potential trigger of the p53 pathway. J Biol Chem 2006; 281: 1196-1204.

5. Adeghate E. Molecular and cellular basis of the aetiology and management of diabetic cardiomyopathy: a short review. Mol Cell Biochem 2004; 261: 187-191.

6. Yahagi N, Shimano H, Matsuzaka T, Sekiya M, Najima Y, Okazaki $\mathrm{S}$, et al. p53 involvement in the pathogenesis of fatty liver disease. $J$ Biol Chem 2004; 279: 20571-20575.

7. Pim D, Banks L. p53 polymorphic variants at codon 72 exert different effects on cell cycle progression. Int J Cancer 2004; 108: 196199.

8. Donehower LA. p53: guardian and suppressor of longevity? Exp Gerontol 2005; 40: 7-9.

9. Campisi J. Cancer and ageing: rival demons? Nat Rev Cancer 2003; 3: 339-349.

10. Van Heemst D, Mooijaart SP, Beekman M, Schreuder J, de Craen AJ, Brandt BW, et al. Variation in the human TP53 gene affects old age survival and cancer mortality. Exp Gerontol 2005; 40: 11-15.

11. Kojima S, Goto $\mathrm{Y}$, Nonogi $\mathrm{H}$, Horie H, Kinoshita M, Iwai N. Role of a p53 polymorphism in luminal narrowing after balloon coronary angioplasty. Atherosclerosis 2000; 151: 585-586.

12. Zee RY, Cook NR, Kim CA, Fernandez-Cruz A, Lindpaintner K. TP53 haplotype-based analysis and incidence of post-angioplasty restenosis. Hum Genet 2004; 114: 386-390.

13. Bonafe M, Salvioli S, Barbi C, Trapassi C, Tocco F, Storci G, et al. The different apoptotic potential of the p53 codon 72 alleles increases with age and modulates in vivo ischaemia-induced cell death. Cell Death Differ 2004; 11: 962-973.

14. Martinez-Lucas P, Moreno-Cuesta J, Garcia-Olmo DC, SanchezSanchez F, Escribano-Martinez J, del Pozo AC, et al. Relationship between the Arg72Pro polymorphism of p53 and outcome for patients with traumatic brain injury. Intensive Care Med 2005; 31 : 1168-1173.

15. Rosenmann H, Meiner Z, Kahana E, Aladjem Z, Friedman G, BenYehuda A, et al. An association study of the codon 72 polymorphism in the pro-apoptotic gene p53 and Alzheimer's disease. Neurosci Lett 2003; 340: 29-32.

16. Ramos LR, Toniolo J, Cendoroglo MS, Garcia JT, Najas MS, Perracini M, et al. Two-year follow-up study of elderly residents in S. Paulo, Brazil: methodology and preliminary results. Rev Saúde Pública 1998; 32: 397-407.

17. Anonymous. Is fasting glucose sufficient to define diabetes? Epidemiological data from 20 European studies. The DECODE-study group. European Diabetes Epidemiology Group. Diabetes epidemiology: collaborative analysis of diagnostic criteria in Europe. Diabetologia 1999; 42: 647-654.

18. Rolland-Cachera MF, Cole TJ, Sempe M, Tichet J, Rossignol C, Charraud A. Body mass index variations: centiles from birth to 87 years. Eur J Clin Nutr 1991; 45: 13-21.

19. Kyle UG, Genton L, Hans D, Karsegard VL, Michel JP, Slosman DO, et al. Total body mass, fat mass, fat-free mass, and skeletal muscle in older people: cross-sectional differences in 60-year-old persons. J Am Geriatr Soc 2001; 49: 1633-1640.

20. Folstein MF, Folstein SE, McHugh PR. "Mini-mental state". A practical method for grading the cognitive state of patients for the clinician. J Psychiatr Res 1975; 12: 189-198.

21. Bertolucci PH, Brucki SM, Campacci SR, Juliano Y. The mini-mental state examination in a general population: impact of educational status. Arq Neuropsiquiatr 1994; 52: 1-7.

22. Bertolucci PH, Okamoto IH, Brucki SM, Siviero MO, Toniolo NJ, Ramos LR. Applicability of the CERAD neuropsychological battery to Brazilian elderly. Arq Neuropsiquiatr 2001; 59: 532-536.

23. Blay SL, Ramos LR, Mari JJ. Validity of a Brazilian version of the Older Americans Resources and Services (OARS) mental health screening questionnaire. J Am Geriatr Soc 1988; 36: 687-692.

24. Bush TL, Miller SR, Golden AL, Hale WE. Self-report and medical record report agreement of selected medical conditions in the elderly. Am J Public Health 1989; 79: 1554-1556.

25. Miller O. Bioquímica do sangue - substâncias não eletrolíticas. In: Miller O (Editor), O laboratório e os métodos de imagem. 5th edn. São Paulo: Atheneu; 2003.

26. Lahiri DK, Nurnberger JI Jr. A rapid non-enzymatic method for the preparation of HMW DNA from blood for RFLP studies. Nucleic Acids Res 1991; 19: 5444.

27. Helland A, Karlsen F, Due EU, Holm R, Kristensen G, BorresenDale A. Mutations in the TP53 gene and protein expression of p53, MDM 2 and p21/WAF-1 in primary cervical carcinomas with no or low human papillomavirus load. Br J Cancer 1998; 78: 69-72.

28. Ara S, Lee PS, Hansen MF, Saya H. Codon 72 polymorphism of the TP53 gene. Nucleic Acids Res 1990; 18: 4961.

29. Emery AEH. Methodology in medical genetics - an introduction to statistical methods. Edinburgh: Longman Group Ltd.; 1986.

30. Cortezzi SS, Provazzi PJS, Sobrinho JSP, Mann-Prado JC, Santos PPR, Freitas S, et al. Associação do polimorfismo p53 e HPV em carcinomas espinocelulares de cabeça e pescoço. $48^{\circ}$ Congresso Nacional de Genética. Águas de Lindóia, September 7-10, 2002.

31. Ojeda JM, Ampuero S, Rojas P, Prado R, Allende JE, Barton SA, et al. p53 codon 72 polymorphism and risk of cervical cancer. Biol Res 2003; 36: 279-283.

32. Suarez Rincon $A E$, Vazquez VE, Ramirez RM, Montoya FH, Covarrubias Rodriguez ML, Sanchez CJ. Squamous intra-epithelial lesions in HIV seropositive females. Their frequency and association with cervical neoplasia risk factors. Ginecol Obstet Mex 2003; 71: 32-43.

33. Barreto SM, Passos VM, Lima-Costa MF. Obesity and underweight among Brazilian elderly: the Bambuí Health and Aging Study. Cad Saúde Pública 2003; 19: 605-612.

34. Abrantes MM, Lamounier JA, Colosimo EA. Overweight and obesity prevalence in Northeast and Southeast Regions of Brazil. Rev Assoc Med Bras 2003; 49: 162-166.

35. Choi BG, Vilahur G, Yadegar D, Viles-Gonzalez JF, Badimon JJ. The role of high-density lipoprotein cholesterol in the prevention and possible treatment of cardiovascular diseases. Curr Mol Med 2006; 6: 571-587.

36. Steinbrecher UP, Parthasarathy S, Leake DS, Witztum JL, Steinberg D. Modification of low density lipoprotein by endothelial cells 
involves lipid peroxidation and degradation of low density lipoprotein phospholipids. Proc Natl Acad Sci USA 1984; 81: 3883-3887.

37. Ehara S, Ueda M, Naruko T, Haze K, Itoh A, Otsuka M, et al. Elevated levels of oxidized low density lipoprotein show a positive relationship with the severity of acute coronary syndromes. Circula- tion 2001; 103: 1955-1960.

38. Rosso A, Balsamo A, Gambino R, Dentelli P, Falcioni R, Cassader $\mathrm{M}$, et al. p53 mediates the accelerated onset of senescence of endothelial progenitor cells in diabetes. $J$ Biol Chem 2006; 281: 4339-4347. 